\section{Woda w kompozycji współczesnych rozwiązań urbanistycznych i krajobrazowych}

\section{Water in composition of contemporary urban and landscape solutions}

\section{Streszczenie}

Celem badan prezentowanych $w$ artykule jest 1/wskazanie możliwości wykorzystania motywów i elementów wodnych w kompozycji urbanistycznej oraz 2/wskazanie współczesnych rozwiązan urbanistycznych i krajobrazowych, stanowiących wybitne przykłady wykorzystania i zastosowania zbiorników i elementów wodnych w przestrzeniach publicznych. wspótczesnych miast.

\section{Summary}

The main purposes of the research presented in the article are following: 1/indication of the possibilities of the use of water Stowa kluczowe: woda, przestrzeń publiczna, zatożenia urbanistyczne i krajobrazowe, miasto, kompozycja

\section{Wprowadzenie}

Kształtowanie zespołów miejskich od najdawniejszych czasów związane było z różnego rodzaju zbiornikami wodnymi, które odgrywały również szczególną rolę w kompozycji urbanistycznej tych zespołów. Pragnienie kontaktu $z$ woda realizowano przez wprowadzanie jej w obręb zabudowy miejskiej na tereny o funkcjach mieszkalnych, jak i publicznych.

Jednym $z$ podstawowych elementów kompozycji urbanistycznej jest podłoga urbanistyczna terenowa o rożnym uktadzie topograficznym, w ktorej stosuje się rożnorodne molywy wodne oraz podłoga wodna, którą mogą być tafle wodne rzek, jezior, porty, kanały wodne, baseny. Zmienność elementu, jakim jest woda powoduje w kazdym momencie odmienne wrazenia u obserwatora, zaležne od pory roku, klimatu, oświetlenia naturalnego i sztucznego. Wrażenia te wzmacniane sa poprzez efekt odbijania w tafli wodnej całego otoczenia, co zwiększa pozornie jego wysokość. Wykorzystywanie wody w kompozycji założeń urbanistycznych i krajobrazowych wpływa na ksztaltowanie tożsamości danego miejsca, a nawet całego miasta.

„Woda - czy jako zbiornik stały, jezioro, staw, basen, czy jako rzeka - stanowi w podłodze urbanistycznej jeden

\section{Introduction}

Shaping urban complexes from the earliest times was associated with various types of water resercomposition of these complexes. The desire to come in contact with water was implemented by introducing it into the city's areas with mainly residential and public functions.

One of the basic elements of urban composition is the urban floor with various topographic layout, in which various water motifs are used, as well as water floor, which may be the water surfaces of rivers, lakes, ports, water channels and pools. The changeability of the water element, causes at any time a different impression at the observer, depending on the season, climate, natural and artificial lighting. These impressions are strengthened by the effect of reflecting in the water surface the entire surroundings, what increases apparently its height. The use of water in the composition of urban and landscape complexes influence shaping the identity of a place, and even of "Water - chether

Whatural reservoir, lake, pond always changing elements in the urban floor. Reflectvoirs, which also played a special role in the urban z niezwykle ciekawych i zawsze zmiennych elementow. powi wspólna tonacie, zwiększa pozornie ich wysokośc i wiąże obraz w całość, w którym występuja linie pionowe rzeczywiste $i$ odbite w tafli wodnej. Zmiennośc tafli wodnej w zależności od oświetlenia, wiatru, koloru wody stanowi bogate tworzywo dla kompozycji urbanistycznej. ... Tafla wodna jako element poziomy wprowadza w układ podłogi, pomimo różnych zmian atmosferycznych, wrażenie spokoju i statyczności" 1

2. Rola zbiorników i elementów wodnych w krajobrazie miast

Przykładów podfogi wodnej o różnych formach i znaczeniu można przytoczyć niekończacy sie szereg - od Canale Grande w Wenecii - wielkiej, ruchliwej arteri ulicznej. Mottawy w Gdańsku z niezrównanymi ścianami, sy/wetą żurawia i starych spichrzów, wielkich, tęt niących nieustannym ruchem portów Marsylii, Hamburga, aż do małych form basenów, fontann i wodotrysków wykwitających z tafli wodnej"2

Procesy związane $z$ podkreślaniem roli wody w krajobrazie współczesnych miast można podzielić na dwa główne kierunki: 1/rewitalizacja istniejących założeń, 2/ksztaltowanie nowych załozen. Wspołczesne miasta, zwłaszcza duze to skomplikowane struktury funkcjonano- przestrzenne, w których woda ciągle odgrywa znacząca rolę. Jednakze uwzględnianie istniejących zbiorników wodnych lub wprowadzanie nowych elementów wodnych jest procesem w różnych skalach. W skali największej, w planowaniu rozwoju miasta przekształceniom poddawane sa miejsca spotkania miasta $z$ woda ( $z$ dużym istniejącym zbiornikiem wodnym). Proces obejmuje ksztattowanie brzegów rzek, jezior, nabrzeży mórz i oceanów (tzww waterfronty). Głównym motywem działań jest konieczność rewitalizacii zaniedbanych, opuszczonych lub nieprzystosowanych do wspótczesnych funkcii obszarów i przywracanie rzeki miastu, zmiany dotychczasowych funkcji obszarów (np. w przypadku dawnych obszán premystowych i portowych) o kztatowa nowych zaloźn zgodnie ze wspótczestymi potzebami (wy ty rozWijajace sie po wzeby rekrea mi potzebami (w tym rozw wajace się potrzeby rekreaci - wypoczynku czynnego i biernego, potrzeby kulturaln reprezentacyjne

Do najciekawszych przykładów projektów założeń nadwodnych w dużej skali należą: rewitalizacja nabrzeży rzeki w Ljubljanie (Cankar Embankment), projekt HafenCity w Hamburgu ( $w$ tym place nabrzeżne Magellan-Terrassen i Marco-Polo Terrassen) (II.1,II.2), Jungfernstieg w Hamburgu, Spreebogen w Berlinie (w tym projek Bürgerforum -punktowe fontanny, tworzące układ nieregularnych strumieni wody) (II.3,4,5), Rummelsburger Bucht i Stralau Peninsula oraz Wasserstadt Spandau w Berlinie, Donaucity, Donauinsel, Wohnpark Neue Donau w Wiedniu, Canary Wharf w Londynie, Madrid Rio w Madrycie, Melaan w Mechelen w Belgii, Rheinuferpromenade w Düsseldorfie, Westhafen we Frankfurcie nad ing the color of the sky and urban walls, giving the floor and cillng a somy and urban walls, git increases apparently their height and links the image into a whole, in which there are vertical real lines and vertical lines reflected in the water surface. The changeability of the water surface depending on the lighting, wind and color of water, is a considerable material for urban composition. ... The water surface as a horizontal element, introduces into the urban floor system, despite various atmospheric changes, an impression of calm and stability"

2. The role of water reservoirs and water elements in the landscape of cities

"Examples of water floors of various forms and meanings can be presented in number of cases from the Grand Canal in Venice - a large, busy water street, Mottawa in Gdansk - with walls, a crane silhouette and old granaries, large, vibrant with the constant traffic ports of Marseilles, Hamburg up to small forms of pools, fountains and water jets that emerge form the water's surface"

Processes related to emphasizing the role of water in the landscape of contemporary cities can be divided into two main directions: $1 /$ revitalization of existing areas, 2/shaping new solutions. Contemporary cilies, especially large ones, are complex funt pay and spectialy structures, in which water stil plays a significant role. How

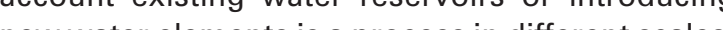
In the largest scale, in planing the city's developIn the largest scale, in planning the city's developmets the water (places of meting with a large existing water reservoir). The process includes shaping banks of rivers, lakes, seash incs and ocehes (so-called watefront. The main motive f the activities is the need of revitalization of nelected, abandoned or not adapted to contemporary functions areas and restoring river to the city, changes of existing functions of areas (e.g in the case of former industrial and port areas) as well as shaping new complexes according to contemporary needs (including the growing needs of active and pasive recreation, cultural and representative needs).

The most interesting examples of large-scale waterfront projects include: revitalization of the river embankment in Liubliana (Cankar Embankment), The HafenCity project in Hamburg (including The Magellan-Terrassen and Marco-Polo Terrassen coastal squares) (III.1, III.2), Jungfernstieg in Hamburg, Spreebogen in Berlin (including The Bürgerforum project - point fountains, creating a system of irregular streams of water) (III.3,4,5), Rummelsburger Bucht, Stralau Peninsula and Wasserstadt Spandau in Berlin, Donaucity, Donauinsel, Wohnpark Neue Donau in Vienna, Canary Wharf in London, Madrid Rio in Madrid, Melaan in Mechelen in Belgium, Rheinuferpromenade in Düsseldort, 


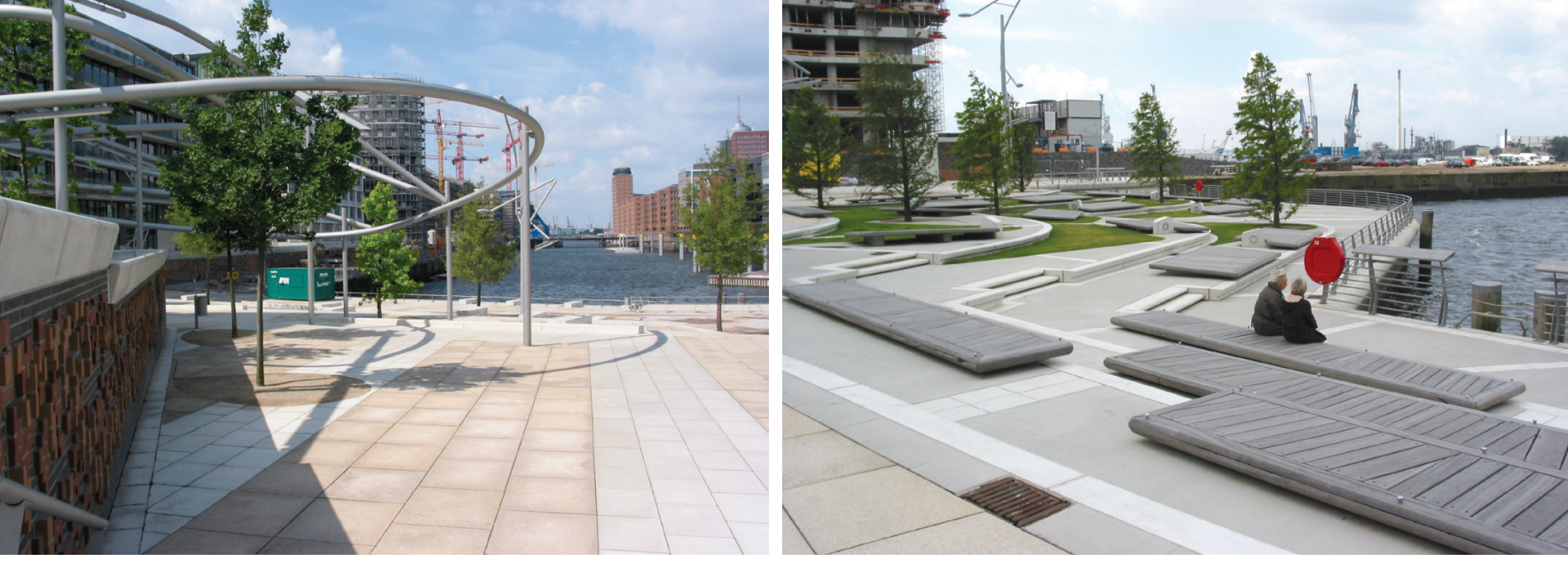

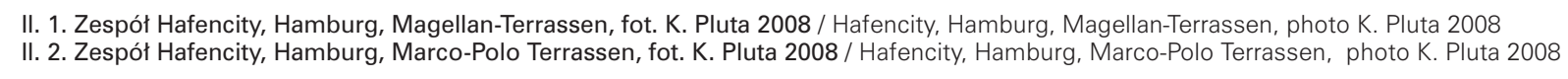
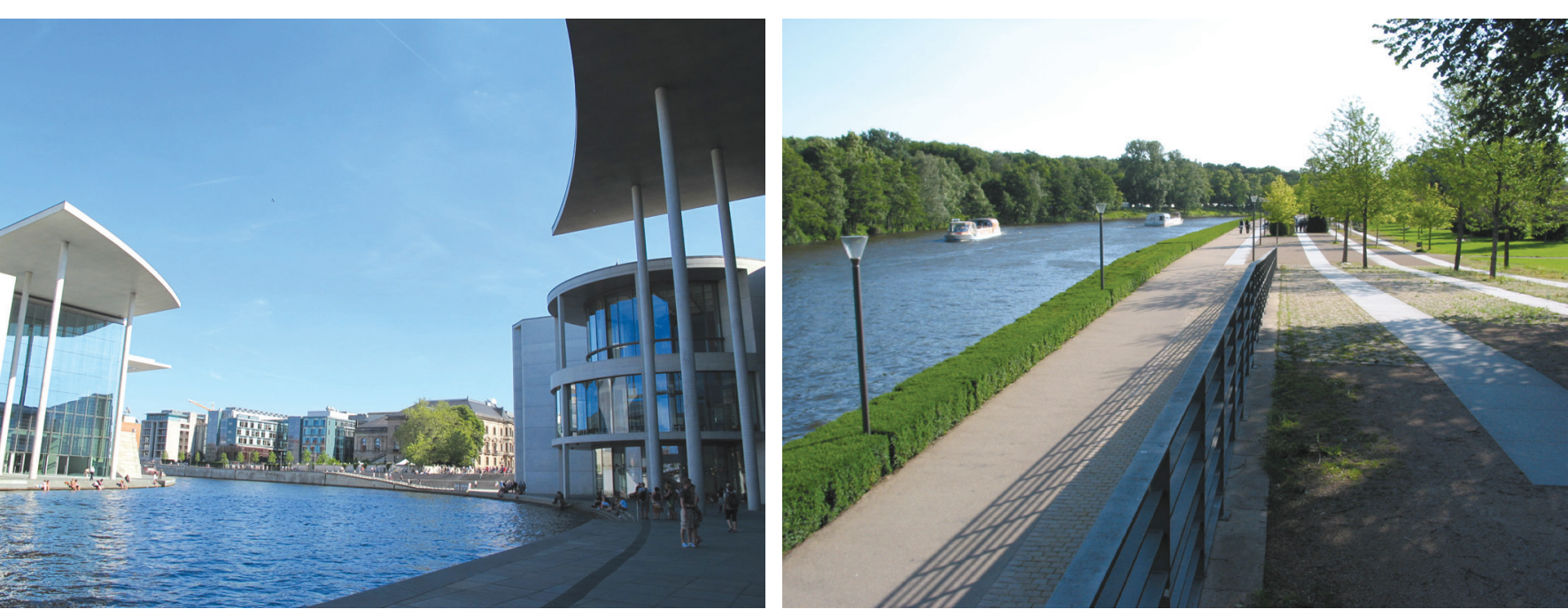

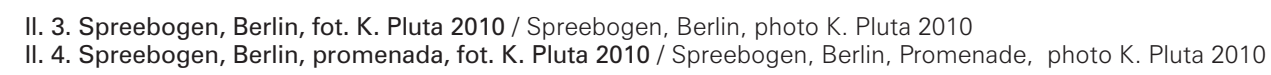

Menem, Cheonggyecheon w Seulu, projekty nabrzeży morskich w Barcelonie (South-west Coastal Park, North-east Coastal Park, Parc Del Litorial), projekty promenad i parków nad rzeką w Paryżu -Seine Rive-Gauche -Parc Bercy (II.6,7), Parc Citroën i w Londynie - Jubilee GarBercy $(11.6,7)$, Parc Cltroen i w Londynie - Jubilee Gardens, Potters Field Park, Than was Barier Park, Royal Victoria Square, projekt Kop van Zuid w Rotterdamie, Inner Harbor w Duisburgu, Clté International w Lyonie, Rheinauhafen w Kolonii, Seafront w Brighton, Aker Brygge w Oslo, projekty zespolów osiedli wraz z parkami w Malmö, Helsinkach, Sztokholmie, Kopenhadze, Clyde Waterfront w Glasgow, Albert Dock w Liverpool, Castlefield and Salford Quays w Manchesterze, Riva Split w Chorwacji, Garcia Da Orta Garden w Lizbonie, Canberra Central Parklands, Pirrama Park w Sydney, Qianjing City Balcony w Hangzhou w Chinach, Sai Gon Pearl w Ho Chi Minh City w Wietnamie, itd.

Do najciekawszych przykładów zastosowania elementów wodnych w zespołach urbanistycznych ksztaftowanych w dużej skali należą: Potsdamer Platz, w tym Sony Center, Beisheim-Center w Berlinie (II.8,9), La Défense w Paryżu, itd. Interesujące są także nowe założenia nadrzeczne i nadmorskie w miastach polskich: Warszawie,
Westhafen in Frankfurt am Main, Cheonggyecheon in Seoul, waterfront projects in Barcelona (Southwest Coastal Park, North-east Coastal Park, Parc Del Litorial), projects of promenades and parks on the river in Paris - Seine Rive-Gauche -Parc Bercy (III.6.7), Parc Citroën and in London - Jubilee Gardens, Potters Field Park, Thames Barrier Park, Royal Victoria Square, The Kop van Zuid project in Rotterdam, Inner Harbor in Duisburg, Cité International in Lyon, Rheinauhafen in Cologne, Seafront in Brighton, Aker Brygge in Oslo, housing complex projects with parks in Malmö, Helsinki, Stockholm, Copenhagen, Clyde Waterfront in Glasgow, Albert Dock in Liverpool, Castlefield and Salford Quays in Manchester, Riva Split in Croatia, Garcia Da Orta Garden in Lisbon, Canberra Central Parklands, Pirrama Park in Sydney, Qianjing City Balcony in Hangzhou in China, Sai Gon Pearl in Ho Chi Minh City in Vietnam, etc.

The most interesting examples of the use of water elements in large-scale urban complexes include: Center in Berlin (III.8,9), La Défense in Paris, etc. There are also interesting new riverside and seaside Potsdamer Platz, including Sony Center, Beisheim-
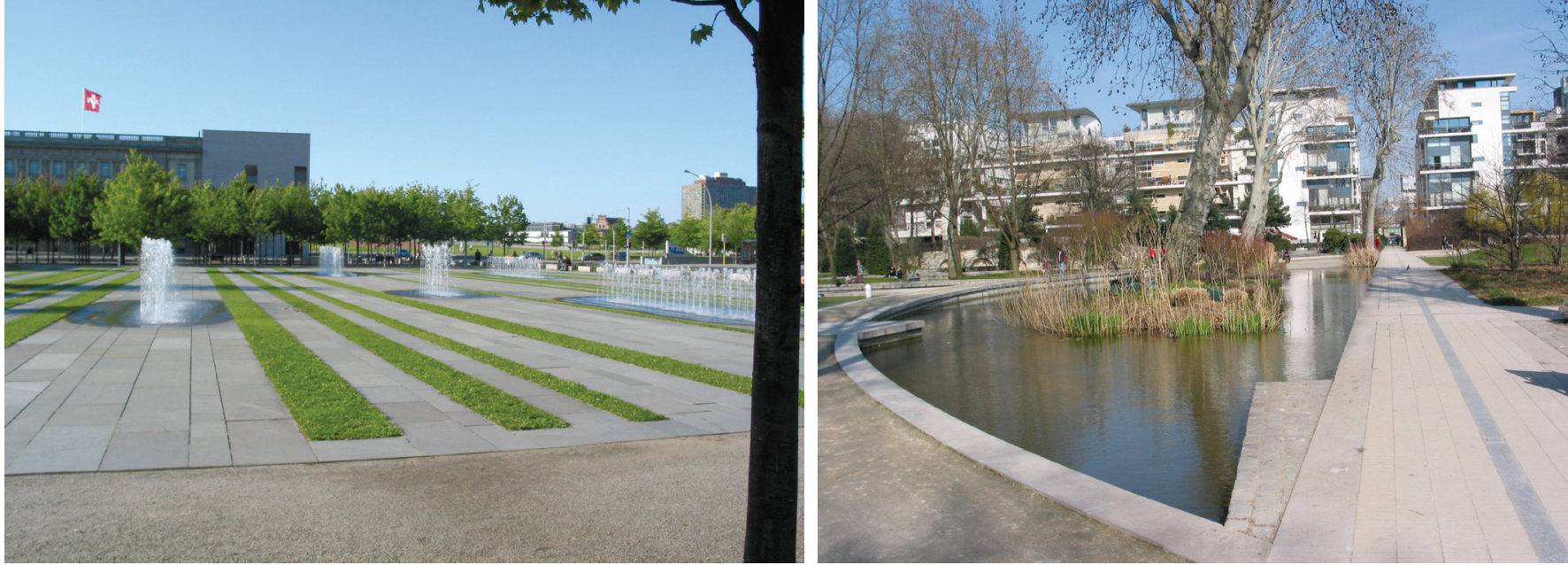

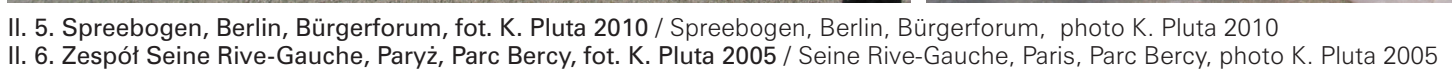
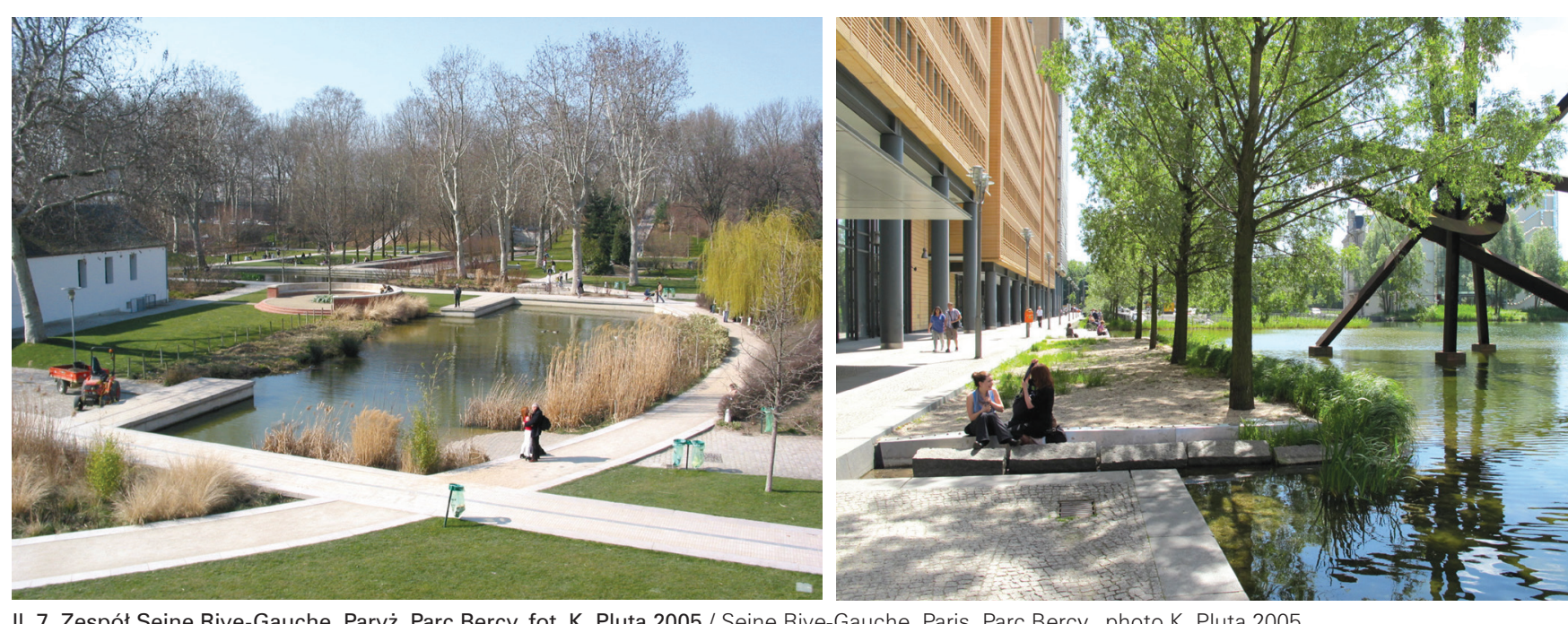

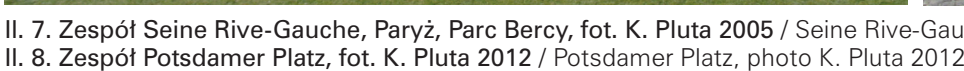

Krakowie, Toruniu, Bydgoszczy, Poznaniu, Wrocławiu, Gdyni, Gdańsku, Sopocie i Szczecinie.

Ważne założenia w duziej skali stanowia takíe parki inne założenia krajobrazowe znajduiace sie gtómnie na obreżach miast, w których wykorzystuje sie czesto istniejace cieki wodne jako glómye motywy kompozycii zaloże Wprowa sie takie nowe elementy wodne $N$ ajcieWawsze pryka ty parków krajobrazowy z element . galii (tafla wodna polazzona kana galin - (ǵb́nt kompozycyjny), Bad Wildungen w Niemczech (głównym motywem parku są kanały wodne), Kulturpark Westergasfabriek w Amsterdamie w Holandii, park krajobrazowe Weinbergwiesen i Wietzepark w Niem czech, park krajobrazowy Duisburg-Nord w Duisburgu, Löbauer Wasser Park w Niemczech, Meran Thermal Bath I Spa Park w Meran we Włoszech, The Australian Garden w Cranbourne w Australii, Kunshan Lotus Lake Park w Kunshan i Tanghe River Park w Qinhuangdao w Chinach, Bishan Park w Singapore, Republic of Singapore Herzeliya Park w Herzeliya w Izraelu, itd. ${ }^{4}$

W strukturze przestrzennej miasta główne przestrzenie publiczne $w$ skali mniejszej niz przestrzen nabrzezy to solutions in Polish cities: Warsaw, Cracow, Toruń, Bydgoszcz, Poznań, Wrocław, Gdynia, Gdańsk, Sopot and Szczecin.

Important solutions in a large scale are also parks and other landscape solutions located mainly on the outskirts of cities, where existing watercourses are often used as the main motives of the composition of these solutions. New water elements are also introduced. The most interesting examples of landscape parks with water elements are: Parque Linear de Ourém in Ourém in Portugal (water surface connected by canals with the river - as the main compositional element), Bad Wildungen in Germany (the main motif of the park are water channels), Kulturpark Westergasfabriek in Amsterdam in the Netherlands, landscape parks Weinbergwiesen and Wietzepark in Germany, landscape park DuisburgNord in Duisburg, Löbauer Wasser Park in Germany, Meran Thermal Bath and Spa Park in Meran in Italy, The Australian Garden in Cranbourne in Australia, Kunshan Lotus Lake Park in Kunshan and Tanghe River Park in Qinhuangdao in China, Bishan Park in Singapore, Republic of Singapore, Herzeliya Park in Herzeliya in Israel, etc. 


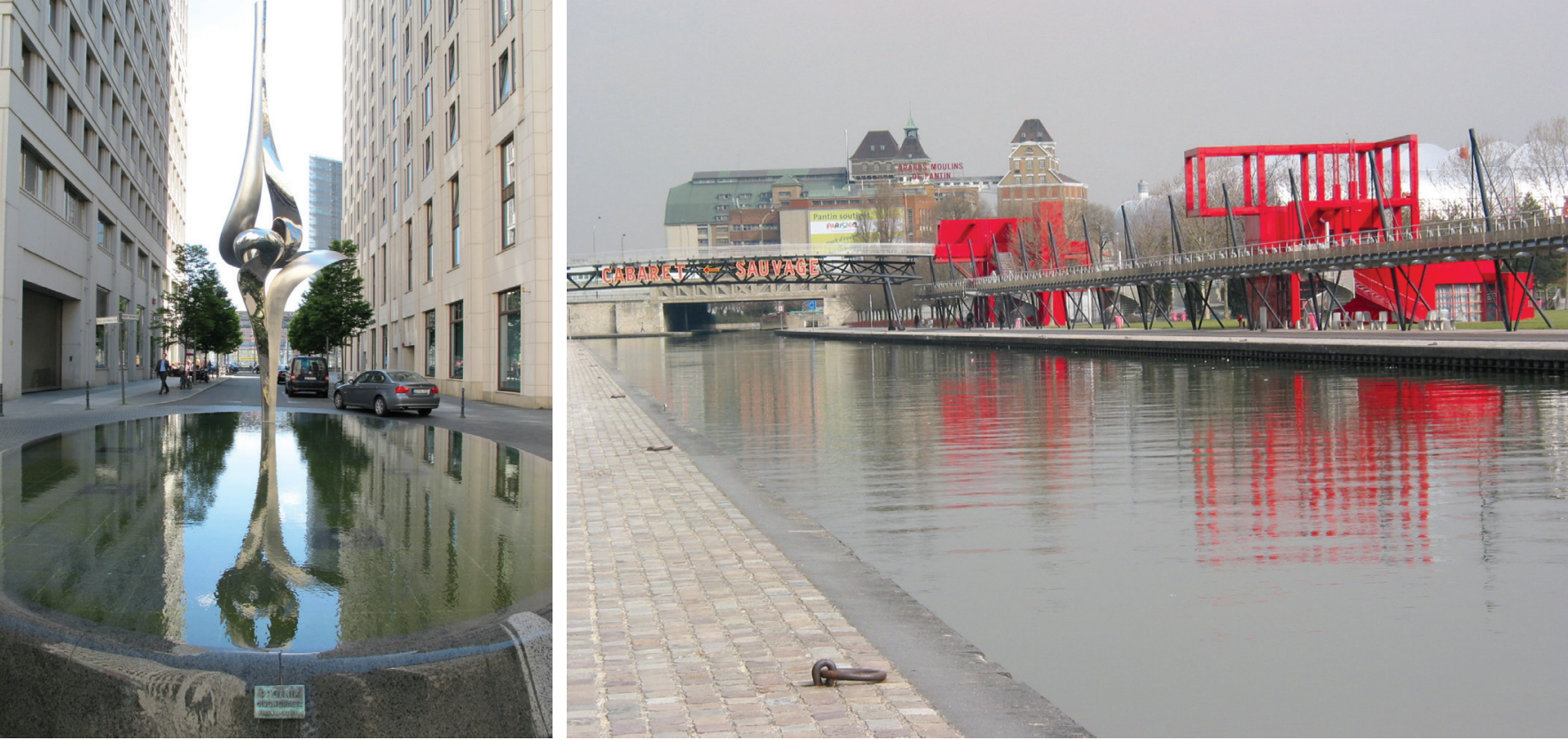

11. 9. Rejon Potsdamer Platz, element wodny w zespole mieszkaniowym, fot. K. Pluta 2012 / Area of Potsdamer Platz, water element in the housing complex, photo K. Pluta 2012
II. 10. Parc de la villette, Paryż, fot. K. Pluta 2005 / Parc de la Villette, Paryż, photo K. Pluta 2005

ulice i place oraz parki miejskie. Obecnie zastosowanie wszelkiego rodzaju elementów wodnych w projektach rewitalizacji tego rodzaju przestrzeni publicznych oraz w projektach nowych przestrzeni publicznych jest bardzo częste. Podjęte badania dotyczące zagadnienia roli wody w krajobrazie miasta, a w szczególności w kompozycji wspótczesnych rozwiązań urbanistycznych i krajobrazowych koncentrowały się głównie na tego typu założeniach. W procesie rewitalizacji placów, ulic i parków miejskich bardzo często istniejące zbiorniki i elementy wodne stanowią jeden z głównych elementów nowej kompozycji założenia. Wprowadza się także nowe motywy wodne głównie w postaci basenów wodnych, kanałów, fontann i ścian wodnych. Ze względu na bardzo dużą ilość rozmaitych rozwiązań w artykule przedstawione sa przykłady przestrzeni publicznych w których woda w znacznym stopniu wpływa na tożsa mość danego założenia. Na placach stosuje sie baseny wodne lub paskie zbiorniki wodne o różnych kszatatach, wspóttworzace podłoge wnetrza urbanistycznsztaltach ty wodne ó́żnej szerokości, podkreślajace cze, kanaty wodne o ozze szeroksci, podkesly ace często kieplacu lub ulicy, ścian wodne o ŕżej wysoḱci, wo placu lub hlicy, scian wodn or rzące zamkniecia przestrzeni, oźnego fodzaju fontanny powiza zezpioste tryskające bezpostednio z posadzki placu czy ulicy. Elementami wprowadzajacymi moty wuchu do przestrzeni publicznych są fontanny, kanały oraz sciany wodne Dzięki nowym technologiom fontanny są programowane $w$ rożny sposob, a w nocy dodatkowo podświetlane świattem o różnych barwach, tworząc współczesn barwne kompozycje, stanowiące często znak szczególny, a nawet dominantę przestrzenną w krajobrazie miasta. Specyficznym rodzajem fontanny jest urządzenie emitujące parę wodną, która przemieszcza się w różne strony w przestrzeni publicznej wchodząc w bezpośredni kontakt z użytkownikami, wywołując efekt chłodzenia
In the spatial structure of the city, the main public spaces in the scale smaller than the space of the quays are streets and squares as well as city parks. At present, the use of all kinds of water elements lic spaecs of revitalzation of this type of public spaces and in projects of new public spaces is ing the ron of water in landscape of cities, and in particular in the composition of contemporand pan and landscape solutions, focused many urhis type of solutions. In the process of revitizaion type of solutions. In the process of revitalizaexisting reservoirs and water elements are onten the main elements of new composition of the soluion. There are also introduced new water motifs, minly in the form of water pools, canals, fount and water walls. There is a large number of various solutions, so in the article there are presented examples of public spaces in which water considerably influences the identity of a solution. squares there a hich inter water pools or flat water sufaces of various shapes, co-creating the urban floor of the urban interior, water channels of various widths, often emphasizing the direction character of the composition of the urb intion the square or street, water walls of various heights creating closures, various types of fountains linked with small-scale water reservoirs or squirt directly from the square or street. The elements introducing the motif of movement into public spaces are fountains, water canals and water walls. Thanks to new technologies, fountains are programmed in various ways, and at night additionally illuminated by light of different colors, creating contemporery colorful compositions, often being a special sign, and even a spatial dominant in the landscape of the city. A specific type of fountain is a installation emitting water vapor, which moves in various directions in the public space, coming into direct contact with

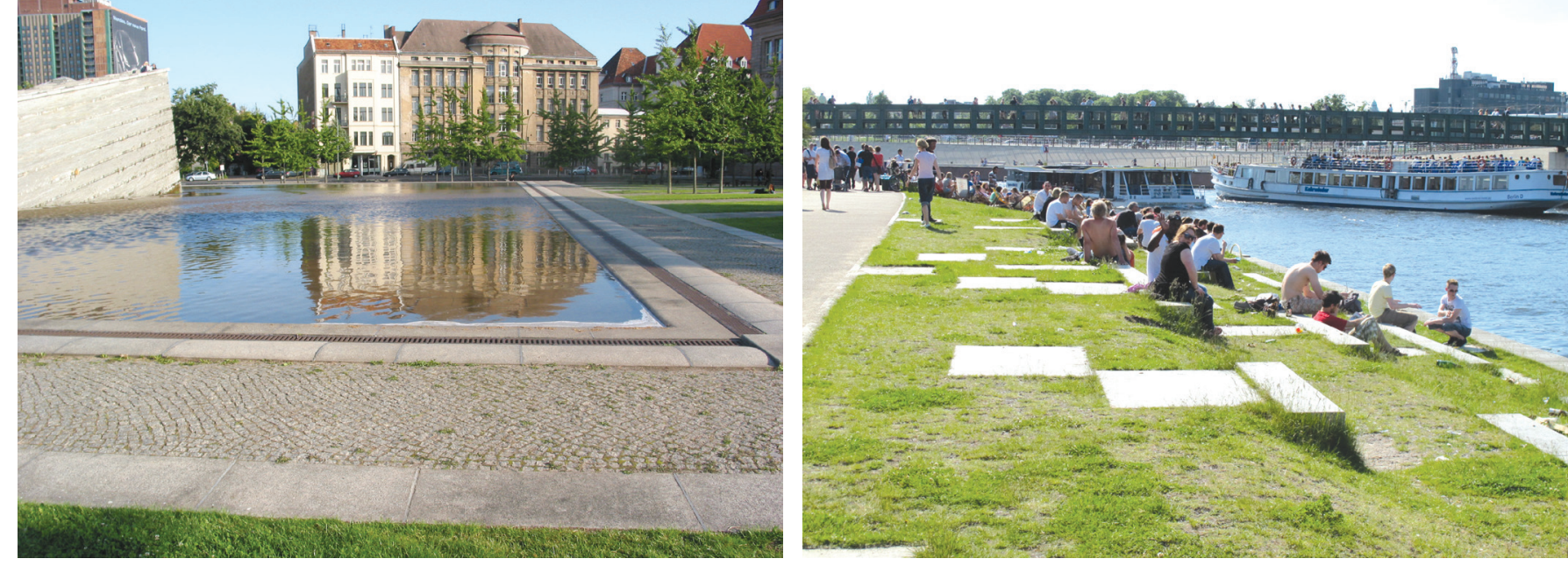

II. 11. Invalidenpark, Berlin, fot. K. Pluta 2012/ Invalidenpark, Berlin, photo K. Pluta 2012
II. 12. Spreebogenpark, Berlin, nabrzeża promenada, fot. K. Pluta 2009 / Spreebogenpark, Berlin, coastal promenade, fot. K. Pluta 2009

w okresie letnim. Natomiast w okresie zimowym często płytkie baseny wor stużace aktywnej rekreacii (lodowiska do jazdy na tyz suzące akty wej rekreacji (lodowiska do jazdy na łyż wach), zwłaszcza w krajach położonych w strefie pół
nocnej klimatu umiarkowanego.

Do najciekawszych przykładów rozwiązań należą: Place des Terreaux (w środkowej części placu w kwadratowych polach usytuowanych jest 69 fontann), Plac de la République w Lyonie, plac Axeltorv (okrągły basen wodny w środkowej części) i plac Sankt Hans Torv (na placu rzeźba-fontanna) w Kopenhadze, place Exchange Square, Piccadilly Gardens, Castlefield and Salford Quays w Manchesterze, City Squares w Bristolu, Exhale Project - 140 West Plaza w Chapel Hill, NC w USA, National September 11 Memorial i The Edge w New York City, NY, USA, Place Des Nations w Genewie, itd. $W$ parkach miejskich następuje ścisłe powiązanie zbiornika wodnego z kompozycją całego założenia. Często zbiornik wodny jest centralnym elementem załozenia parkowego, przy nim znajdują się różne urządzenia typu amfiteatr, pawilony usługowe, pomosty i mola do obserwacji widoków oraz ścieżki piesze i rowerowe na brzegach. Projekty przestrzeni publicznych są przedmiotem pracy wielobranżowych zespołów projektowych oraz powstają często we współpracy i przy konsultacji lokalnych społeczności.

Do najciekawszych przykładów rozwiązań parków miejskich z motywami wodnymi należa: Parc de la Villette w Paryżu (II. 10) Invalidenpark w Berlinie (II.11) projekt Spreebonpark w Berlinie (nabrzeżna promenada nad De Szrewa z trawiasta plazą opadajaca w kierunku brze .

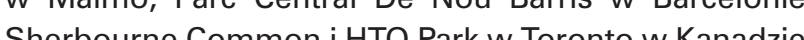
Washinn Com Wash side Fountain Park W Bremerton, WA, USA, Millenium Park W Chicago, IL, USA, Tanner Springs Park w Portland OR, USA, Juan Carlos I Park W Madrycie, it.

W małej skali motywy wodne wprowadzane są na skwerach miejskich, w pieszych pasażach zewnętrznych i wewnętrznych oraz w przestrzeniach półpublicznych i społecznych (głównie w osiedlach mieszkaniowych users, causing a cooling effect in the summer. In contrast, in winter, shallow water pools are often transformed into spaces for active recreation (ice skating rinks), especially in countries located in the northern moderate climate zone.

The most interesting solutions are: Place des Terreaux (in the central part of the square, there are 69 fountains located in the square fields), Place de la République in Lyon, Axeltorv square (round water pool in the middle part) and Sankt Hans Torv square (in the square -sculpture-fountain) in Copenhagen Exchange Square, Piccadilly Gardens, Castlefield and Salford Quays in Manchester, City Squares in Bristol, Exhale Project - 140 West Plaza in Chape  rial and The Edge in New York City, NY, USA, Place

In urban parks, the water reservoir is closely related to the composition of the entire solution. The water reservoir is often the central element of the park's layout, there are various spatial elements located near it. amphitheater, service pavilions, piers for pservation of views as well as walking and cycling paths along the banks. Projects concerning public spaces are the subject of the work of multi-branch tere often created in cooperation and consultation with local communities.

The most interesting examples of urban parks with water monts are: Parc de la Villette in Paris (III.10), Invalidenpark in Berlin (II.11), Spreebogenpark in Berlin (coastal promenade on the Spree river with a grassy beach descending towards the river Warden in Nancy, Anchor Park in Malmo, Parc Central De Nou Barris in Barcelona, Sherbourne Common and HTO Park in Toronto in USA, Washington Canal Park in Washington DC, USA, Mrorside Fountain Park in Bremerton, WA, USA, Minenim Park in Chicago, IL, USA, Tanner in Madrid, etc. ${ }^{\circ}$

in a smill sca, water moifs are intoduced in smal city squiscale, water motifs are introduced in smal city squares, in pedestrian external and internal passages, and in semi-public and social spaces (mainly in housing estates and spaces that accompany vari- 


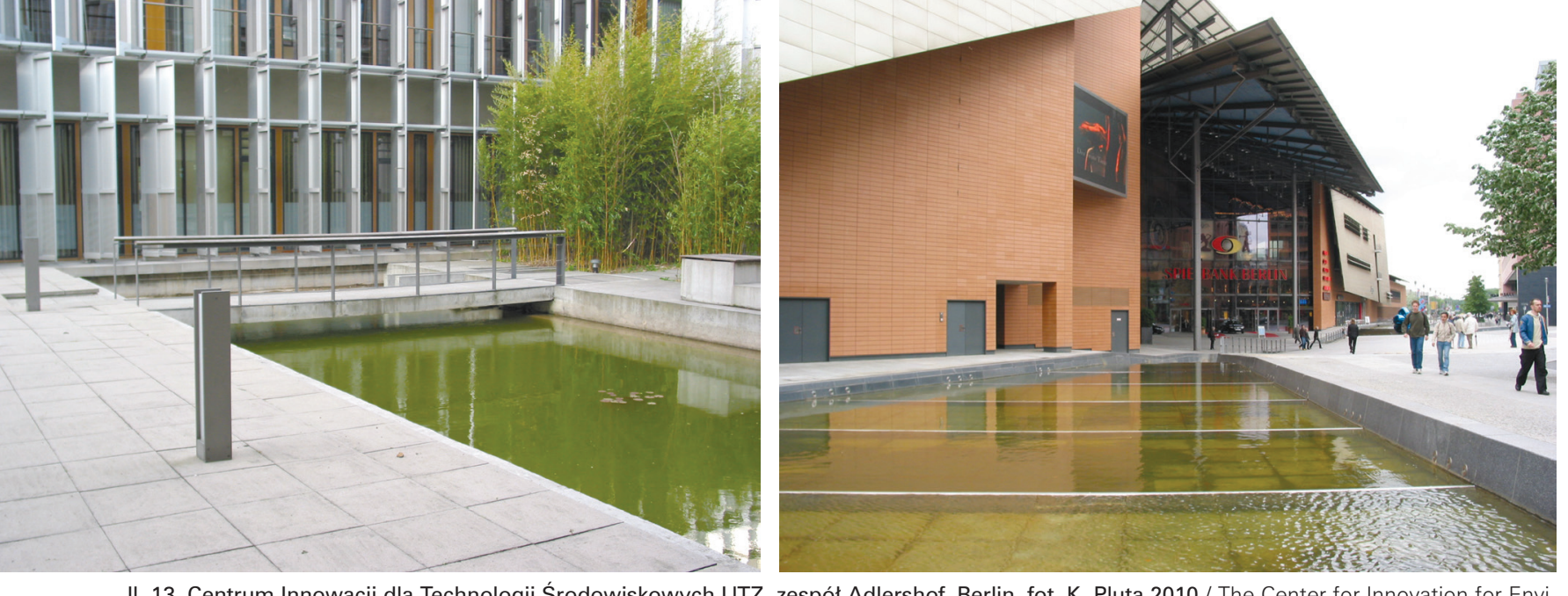

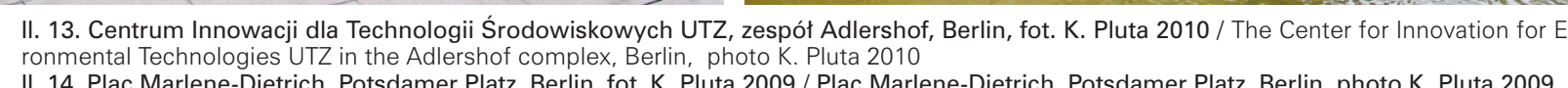

i w przestrzeniach towarzyszących różnym instytucjom, np. projekt dziedzińca w Centrum Innowacji dla Technologii Środowiskowych UTZ w zespole Adlershof w Berlinie) (II.13). Elementy wodne wprowadzane sa także $w$ przestrzeniach prywatnych $w$ formie basenów kąpielowych i założeń wodnych (oczka, kaskady, kanały, fontanny), co wzbogaca krajobraz i wpływa pozytywnie na mikroklimat miasta.

3. Motywy i elementy wodne w przestrzeni placów i ulic - baseny wodne

3.1. Abbey Square Averbode, Averbode, Belgia 2013, proj. Omgeving Landscape architects.

Interesującym przykładem integracji architektury i wody jest projekt rewitalizacji dziedzińca przed opactwem Averbode w Belgii. Głównym elementem przestrzennym nowej aranżacji placu jest płytki basen wodny (o głẹbokości paru centymetrów). Przestrzeń dziedzińca wspótworza takze inne elom) Pry przzeń dziedzińca drzewa Tilia mur, brukowane piesze obejście bare (a)

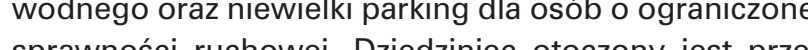
sprawnosci ruches przez his odbijaja się w tafli wodnej basenu. Woda moze zostac także osuszona, zwiększajac w wa powierzchnię uzytkowa dziedzinca dla organizacj roinych wydarzen. W nocy budowle znajdujące się przy placu są oświetlone, zasto sowano także paski LED, podkreslające pieszą ściezkę̨ . Basen wodny jest istotnym elementem kompozycji prze strzennej dziedzinca. Basen usytuowany jest centralnie na przedłużeniu głównej osi Kościoła i zajmuje dużą powierzchnię na posadzce placu. Osiowość kompozycji podkreślona jest także przez pojedynczy szpaler drzew, znajdujących się od strony zachodniej i poludniowej dziedzińca. Dzięki znacznej wielkości basenu wodnego, historyczne wnętrze urbanistyczne o rzucie zblizonym do kwadrat (w części południowej nieznacznie rozszerzone) - posiad podłogę urbanistyczną, która ukształtowana jest głównie przez powierzchnię wodną, odbijającą historyczne ściany wnętrza. Tafla wodna wprowadza element ruchu i zmienności do wnętrza urbanistycznego o charakterze regular- ous institutions, e.g. courtyard in the Center for Innovation for Environmental Technologies UTZ in the Adlershof complex in Berlin) (III.13). Water element swimming pools and water reservoirs (ponds, cascades, canals, fountains), What entiches the landof the city.

\section{Water motifs and water elements in the space}

\section{f squares and streets - water pools}

3.1.Abbey Square Averbode, Averbode, Belgium 2013, designed by Omgeving Landscape architects. An interesting example of the integration of archthe courtyard in front project of revtalization of Belgium. The main spatial element of the new arrangement of the square is a shallow water pool (with a depth of a few centimetres). The space of the courtyard is also co-created by other spatia elements: the old Tilia trees, the old wall, the cobblestone pedestrian path around the water pool and a small parking space for visitors with reduced mobility. The courtyard is surrounded by historic buildings (church, palaces) whose facades are reflected in the water surface of the pool. The water can also courtyard for the organization of various events. At night, the buildings at the square are illuminated, LED strips are also used, emphasizing the walking path?

The water pool is an important element of the spatial composition of the courtyard. The pool is located centrally on the extension of the main axis of the church and occupies a large area on the floor of the square. The alignment of the composition is also emphasized by a single row of trees located on the western and southern sides of the courtyard. Due to the large size of the water pool, the historic urban interio with a square-like plan (slightly enlarged in the southern part) has an urban floor, which is shaped mainly by the water surface reflecting the historical walls of urban interior. The water surface introduces an elare also introduced in private spaces in the form of be drained, thus increasing the usable area of the nym i statycznym, gdyz odbija zarowno fasady oświetlone jest elementem jeszcze dynamiczniej zmiennym. Odbicia budowli w tafli wodnej widoczne są także w nocy dzięk podświetleniu obiektów architektonicznych.

\subsection{Fontana Square, Rozzano, Włochy, 2009,}

\section{proj. Labics.}

Projektem, w którym woda jest jednym z elementów kompozycji całego załozienia, jest projekt urbanistyczny placu miejskiego Fontana Square w Rozzano na przed mieściach Mediolanu. Projekt stanowi próbe uksztatowania prestreni miskiej o wyrajiste toisamosci, elastycznej i zaspokają̧ej wiele różych wymagan

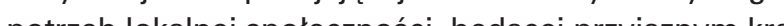

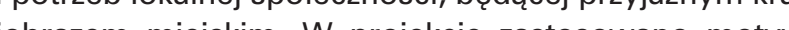
jó́ trojkąta wpleciony $w$ prostokątną siatkę podziałów zaPadniczych posadzki placus.

Plac miejski Fontana Square w Rozzano jest regularnym wnętrzem urbanistycznym o kształcie prostokąta, oto czonym wspołczesną zabudową mieszkaniowo- usługową o wysokości do 7 kondygnacji. Podstawą kompozycji nowego zagospodarowania placu jest posadzk podzielona na rozmaite pola powierzchni za pomoca geometrycznej prostokątnej siatki. Dodatkowo niektóre powstałe $w$ ten sposób prostokątne pola (pojedyncze lub kilka wspólnych) podzielono liniami przekątniowymi co stworzyło wzor posadzki placu, w ktorym dominuja trójkątne pola wypełnione rozmaitym tworzywem: nawierzchnią utwardzoną w barwach jasnoszarej i ciemnoszarej, drewnem (w okolicach zgrupowania siedzisk) trawą, krzewami wraz z drzewami oraz wodą. Trójkạtne pola są różnej wielkości. Drzewa nasadzono na placu nieregularnie zarówno na powierzchniach utwardzonych jak i trawiastych. Powierzchnie wodne tworza dwa płytkie tróikatne zbiorniki usytuowane w centralnej cześci

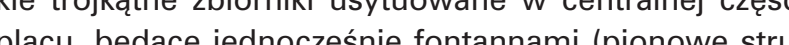
mienie wody o wysokości ok $50 \mathrm{~cm}$ ). Ważnymi elemenmi wompozcil przestzennej placu sa takie lampy oraz w trukcii rómnież zastosowano motyw trókgą (wszystkie

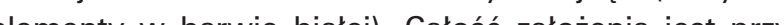

kładem kompozycji nieregularnej ale uporządkowanej,

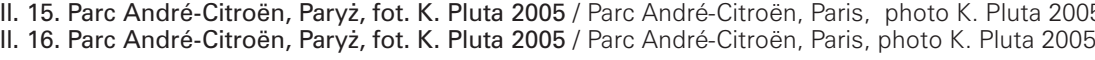

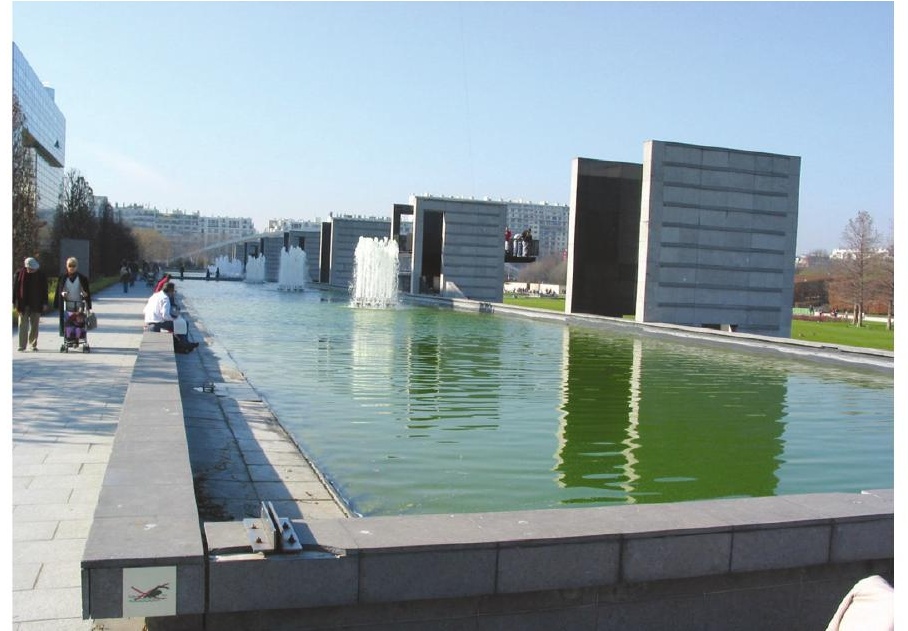

ement of motion and changeability into the urban terior of a regular and static nature, as it reflects both façades illuminated by a different intensity of sulght and the sky, which is an even more dynamic element. Reflections of the buildings in the water suree are also visible at night due to the lighting of

by Labic

The design project, in which water is one of the elements of the composition of the entire space, is the Uan design of public square Fontana Square w Rozzano, a suburb of Milan. The project is an attempt the urban space with a distinctive identity, 作 作 and verporated in a rectangular grid of fundamental divisions of the floor of the square 8 .

The Fontana Square is a regular rectangular urban vice bullings up to 7 storeys. The basis for the vampos is the floor divided into various surface areas using a geometric rectangular grid. In addition, some reter a fle were divided by diagonal lines, what created willeor patern, dominated by triangular fields filled with various materials: paved surfaces in light grey and trianglass, shrubs along with trees and water. The plangular fields are of various sizes. The trees were planted on the square irregularly on both hardened by tro surs surfeses are formed by tho shallow triangular reservoirs located in the (vertical of the square, which are also fountains (ver about $50 \mathrm{~cm}$ high). Imsquare are ans in the spatial composition of the which the lightweight and openwork pavilions, in motif has whole urban spece (an exements in white). The Whe andscape with anposition, creating a new urban

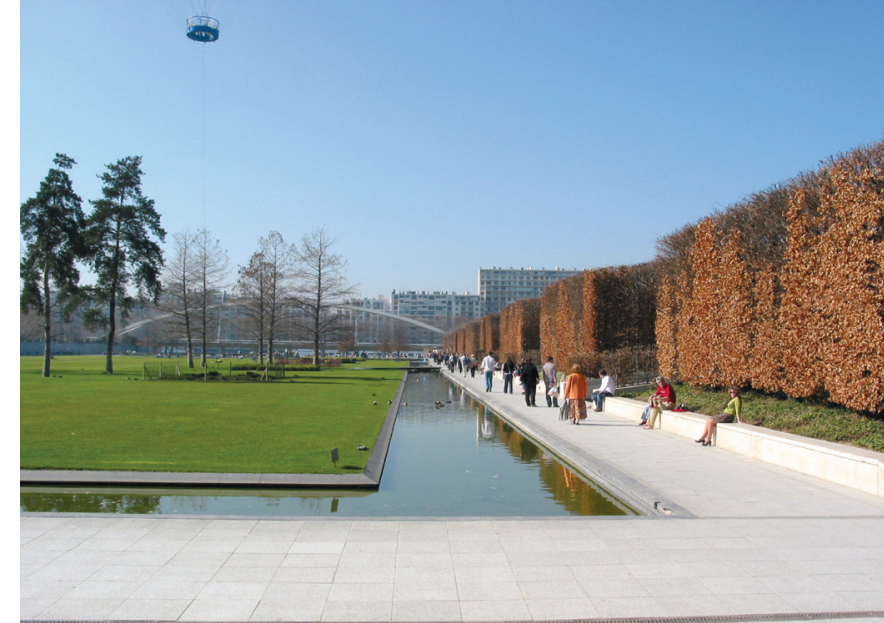


tworząc nowy krajobraz miejski o indywidualnym wyrazie przestrzennym i wysokiej jakosci oraz umożliwiający różny sposób użytkowania - czyli posiadający cechy jakie powinna spełniać współczesna przestrzeń publiczna.

3.3. Water Square Bentheimplein, 2013, proj. De Urbanisten, Rotterdam, Holandia.

W Rotterdamie zrealizowano plac miejski, który nazwano Placem Wodnym - Water Square Bentheimplein. Jest to przestrzé publiczn która ma spetniać różne funkcie to przestren publiczna, ktora w zależności od po mest sucho funkcjonuje jako mejsce do zabawy, uprawiania sportow, odpoczy deszczowa- dwa plytkie baseny oraz jeden glębszy zbiornik, kón zbiera wo ż z wieksego obszaru wokó placu, a kiedy nie pada služy jako boisko spotowe. W projekcie powierzchnie zalewane wodą zaprojektowane są z materiałów w odcieniach niebieskiego, a elementy transportujące wodę wykonane są ze lsniącej stali nierdzewnej. Plac jest wnętrzem urbanistycznym o nieregularnym kształcie, otoczonym zabudową administracyjną i usługową o wysokosci ok. 8 kondygnacji wraz z jednym wyż szym punktowym budynkiem, stanowiącym dominante przestrznna placu. W ten nieregulany uklad przestrzenny wpisano harmonijnie trzy zaglębione obszary o róż nym ksztatcie, pełniące $w$ czasie deszczu rolę zbiorników wodnych, co całkowicie zmienia charakter placu. Plac o utwardzonych nawierzchniach o różnych funkcjach przekształca się wtedy w plac o dominującej podłodze wodnej (trzy zbiorniki zajmuja obszerna powierzchnie placu). Zbiorniki uksztattowane są amfiteatralnie - na niż szy poziom można zejść za pomocą stopni. Amfiteatralne założenie największego centralnego zbiornika tworzy wiele elementów przestrzennych, $w$ tym miejsca do siedze nia wmontowane w stopnic. Na placu znajuja sie taki powierzchnie trawiaste wraz z krzewami i drzewą takze elementy oświetlenia (lampy i linie w posadzce). Catość zatożeni twory kompozycje któnej gónma cecha jest zalożn ó wory kompozyce, kórej glówną cechą jest zraz miejsi o indyidu możliwość różnorodnego sposobu użytrowan.

3.4. Market Square, Guelph, Kanada, 2012, proj. Janet Rosenberg \& Studio.

Podobny przykład placu o zmiennej funkcji dzięki zbiornikowi wodnemu stanowi plac Market Square w Guelph. Głównym elementem zagospodarowania placu przed Ratuszem jest płytki owalny basen wodny, w którym odbija się historyczna fasada Ratusza. W okresie letnim plac jest ważnym miejscem spotkań społeczności lokalnej- organizowane są tutaj koncerty, spektakle, wieczory filmowe, targi, obchody Dnia Kanady. Dzięki zastosowanym dyszom wodnym basen zamienia się $w$ dynamiczną fontannę. W zimie zbiornik wodny funkcjonuje jako lodowisko, co umożliwia także odpowiednie nagłośnienie i strategia oświetleniowa typu LED high-quality and enabling different way of use - that should be met by contemporary public space.

3.3.Water Square Bentheimplein, Rotterdam, The Netherlands, 2013, designed by De Urbanisten.

In Rotterdam, a city square was created, which was called Water Square Bentheimplein. It is a public space that has to fulfil different functions depending on the weather: when it is raining it is flooded and creates a large water reservoir, and when it is dry functions as a place for play, sports, rest and walk. Three pools collect rainwater - two shallow pools and one deeper reservoir that collects water from a larger area around the square, and when it is no raining it serves as a sports ground. In the design the surfaces flooded with water are designed from materials in shades of blue, and the elements tran porting water are made of shiny stainless steel'. The square is an urban interior of irregular shape, surrounded by administrative and service building with a height of approx. 8 floors, together with one higher point building, which is a spatial dominant of the square. In this irregular spatial area, there were harmoniously introduced three recessed areas of various shape, which play the role of water reservoirs during the rain, what completely changes the character of the square. A square with paved suraces of various functions is then transformed into a square with a dominant water floor (three reservors occupy a large area of the square). The resercan be descended using steps. The amphitheatric can be descended using steps. The amphitheatric of spatiol elements, including sitting places mount ed in steps. On the square there are grassy ares with shrubs and trees and lighting elements (lamps and lines in the floor). The whole urban space creates a spatial composition whose main feature is variability thanks to the war ment. A new urban landscape was cre the water elevidual identity, providing the possibility of a va vidual iden.
of uses.

3.4.Market Square, Guelph, Canada, 2012, designed by Janet Rosenberg \& Studio.

A similar example of a square with a variable function thanks to the water reservoir is Market Square in Guelph in Canada. The main element of the velopment of the square in front of the Town Hall is a shallow oval water pool, in which the historic facade of the Town Hall is reflected. In the summer, the square is an important meeting place for the local community - concerts, performances, movie nights, markets, Canada Day celebrations are organized here. Thanks to the water jets, the pool turn into a dynamic fountain. In winter, the water reservoir functions as an ice rink, which is also possible thanks to adequate sound system and a dynamic LED lighting strategy ${ }^{10}$.
Głównym elementem kompozycji prostokątnego wnęnej wielkości otoczony zielenią niską i drzewami. Kompozycja placu jest regularna, a indywidualną tożsamośc przestrzeni publicznej zapewniają detale urbanistycznegłównie dysze wodne o rzeźbiarskich kształtach oraz oświetlenie posadzki i fasad budowli otaczajacych plac.

\section{Motywy i elementy wodne w przestrzeni placów} i ulic - kanały wodne

Ważnym pacem w zespole Potsdamer Platz w Berlini jest plac Marlen wistich (w planie w ksztacie trólkajest plac Maren w ze mfitea mowi 2o Pia christoh Kolbecker) ikasyna. W Konpozyci zo Plano, Chrstoph Kohlbecker) i kasyna. W kompozyci posdze w formie trojk wodne $w$ formie trójkątnych basenów wodnych połączonych mostkami'11. (II.14)

W parku André-Citroën w Paryżu w części środkowe usytuowano obszerną płaszczyznę trawiastą opadając ku rzece, otoczoną od północy szeregiem ogrodów tematycznych wraz z szescioma malymi cieplarniami, a od południa promenadą z prostopadłościennymi punktowymi niewielkimi obiektami z balkonami obserwacynymi oraz towarzyszącym jej kanałem wodnym. Brzeg rozległego trawnika zaprojektowany jest $\mathrm{w}$ formie waskiego kanału wodnego ${ }^{12} .(I I .15,16)$

5. Motywy i elementy wodne w przestrzeni placów i ulic - fontanny

W parku Byparken w Aarhus w Danii (proj. Schønher 2012) znajduje się fontanna w kształcie ścietego od góry stożka usytuowana na trawiastym wzniesieniu ${ }^{13}$.

Interesujący projekt współczesnej fontanny wprowadzono w przestrzeń historycznego placu Piazza Lorenzo Berzieri w Salsomaggiore Terme we Włoszech (proj. Za gospodarowania placu Emilio Faroldi Associati, 2010)14. Fontanna zaprojektowana w forme dwóch przecin. cos cych togi nieregularnego $w$ kszatałcie placu.

W rewitalizacji placu Pariser Platz w Berlinie (realizaW rewitalizacji placu Pariser Platz w Berlinie (realiza cja 1997-2008) W kompozycji nowej posadzki placu wprowadzono dwie wydużone prostokąne zielone powierzchnie (symetrycznie po obu stronach główne osi), na ktorych zaprojektowano specjalne kompozycje roslinne, skladające się z kwiatów, bylin i traw o różnych barwach. W środku powierzchni znajdują się koliste fontanny, a przy krotszych bokach po dwa strzyżone żywopłoty $\mathrm{w}$ formie pótkuli'15. (II.17)

W Strasburgu we Francji poddano rewitalizacji główny plac miasta Place Kleber (proj. Guy Clapot, 1993). W projekcie starano się osiągnąc dwa główne cele: stworzenie interesującej przestrzeni dla pieszych oraz większe zacienienie placu. Nowa posadzka placu wykonana jes z płyt z ciemnego kamienia oraz z wạskich pasm z bia-
The main element of the composition of the rectangular urban interior is an oval water pool of considerable size surrounded by greenery and trees. The composition of the square is regular, and the individual identity of the public space is provided by urban details - mainly water jets of sculptural shapes and lighting of the floor and facades of the buildings surrounding the square.

4. Water motifs and water elements in the space of squares and streets - water channels

An important square in The Potsdamer Platz com plex in Berlin is Marlene-Dietrich square (in the shape of a triangle), shaped on various levels. The urban floor - amphitheatrically descending, is the main entrance to the musical theater (designed by Renzo Piano, Christoph Kohlbecker) and the casino. In the composition of the floor of the square, the characteristic motifs are water channels in the form of triangular water pools connected by pedestrian bridges"11. (III. 14)

In the André-Citroën park in Paris (designed by P.Berger, G.Clément, A.Provost, J.P.Viguier, 1985), in the middle part there is a large grassy surface descending towards the river, surrounded from the north by a number of themed gardens with six small greenhouses, and from the south by a promenade with small rectangular point buildings with observaThe baco of a wide accompaning water channel.

5. Water motifs and water elements in the space of squares and streets - fountains

In the Byparken park in Aarhus, Denmark (designed by Schønherr, 2012), there is a fountain in the shape of a cone cut from the top located on a grassy hill'13. An interesting project of the contemporary fountain has been introduced into the space of the historic Piazza Lorenzo Berzieri square in Salsomaggiore Terme in Italy (designed by Emilio Faroldi Associati, $2010)^{14}$. The fountain, designed in the form of two intersecting planes (rectangular and trapezoidal in shapel) is one of the main spatial elements of the floor of the irregular square.

In the revitalization of the Pariser Platz in Berlin (realized 1997-2008), in the composition of the new floor of the square there were designed two elongated rectangular green surfaces (symmetrically on both sides of the main axis), on which special plant compositions consisting of flowers, perennials and grasses of various colors were introduced. In the middle of the surface there are located circular fountains, and at the shorter sides, two formed hedges in the form of a hemisphere ${ }^{15}$. (III.17)

In Strasbourg, France, the main square of Place Kléber (designed by Guy Clapot, 1993) was revitalized. There were two main aims of this revitalization creation an interesting pedestrian space and bigger shading of the square. The new floor of the square is 
mostów Kalvebod Waves w Kopenhadze. Molo dzięki szerszym platformom stanowi przestrzen publiczną na wodzie zapewniająca możliwość organizacji rozmaitych imprez ${ }^{21}$.

8. Związki obiektów architektonicznych z wodą

Interesujacym przykładem powiazania pojedynczego budynku i jego bezpośredniego otoczenia $z$ woda jes WES LandschaftsArchitektur, 2011). Zespót dwóch budynków biorowych potożony, 2011). Zespót dwóch buprzedzienow jest wewnetrzna przestrzenia puiwyspie

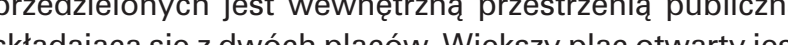

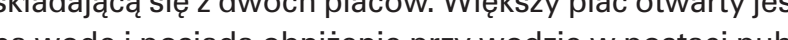
naw

\section{Podsumowanie}

twarte przestrzenie wodne stwarzaja unikatowe moż liwości ekspozycji. Zwłaszcza rzeka umożliwia inną percepcję architektury miasta, co wykorzystywano od dawna, lokalizując w jej sąsiedztwie najważniejsze budowle i zespoły urbanistyczne. Charakter kompozycji krajobrazu nadrzecznego wynika przede wszystkim ze skal rzeki oraz ze sposobu zagospodarowania jej brzegów. Współczesne dynamiczne przekształcenia miast, zwłaszcza dużych nieustannie zmieniają charakter kontaktu rzeki z miastem. W mniejszej skali zastosowanie wody, jako tworzywa dla kompozycji urbanistycznej widoczne jest $\mathrm{w}$ przekształceniach $\mathrm{i}$ rewitalizacji wewnętrznych przestrzeni miast, zwłaszcza w kształtowaniu harmonijnych przestrzeni publicznych. W kompozycji przestrzennej ulic, placów, terenów zieleni i rekreacji stosuje sie elementy zwiazane $z$ woda, takie jak: kanały wodne, tafle wodne, ściany wodne, fontanny, ciagłe strumienie wody, kładki piesze, pływające platformy, specjaln oświetlenie.

Podsumowujac ksztattowanie oryginalnych i o wysoPiej jakości zatozeń urbanistycznych i krajobrazowych w miastach, w kompozyci

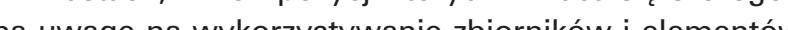
a unge na wy

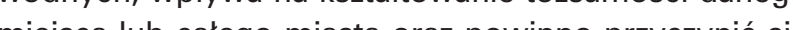
mo po lub calego miasta oraz powinno przyczy ic sie do powstrzymania procesu degradacji i ujednolicania krajobrazu wspólczesnych miast. Zwaszcza wprowadzanie elementów wodnych inspirowanych historią rozwoju okolicy i lokalnym zagospodarowaniem obszaru powoduje zarowno podtrzymanie lokalnego charakter danego miejsca, jak i ksztattowanie nowej tożsamości założenia. Dzięki symbiozie roznorodnych form prze strzennych, zastosowanych materiałów, detali urbanistycznych, elementów wodnych, różnych rodzajów zieleni i oświetlenia sztucznego powstają nowe krajobrazy miejskie.

K. Wejchert, Genenty Kompozzcii Urbanistycznej, Arkady, Warszaw

1974, s. 99.
2 lbidem, s. 100 wing the opportunity to organize various events ${ }^{21}$

A. Integration of architectural objects with water An interesting example of the integration of a single building and its immediate surroundings with water is Spiegel-Haus auf der Ericusspitze in Hambur (designed by WES LandschaftsArchitektur, 2011). A complex of two office buildings located on a smal peninsula is divided by an internal public space consisting of two squares. The larger square is open to water in the form of public promenade ${ }^{22}$.

\section{Summary}

Open water spaces create unique possibilities of exposure. Especially the river enables a differen perception of the city's architecture, what has been used for a long time by location the most important buildings and urban complexes in its vicinity The nature of the riverside landscape composition results mainly from the scale of the river and from the method of development of its banks. Contem porary dynamic transformations of cities, especially large ones, constantly change the nature of the contact between the river and the city. In a smaller scale, he use of water as a materialy position can be observed in transformations and cially in shaping harmonious public spacs, espepatia comprition of streets, squares, green and ccreation areas there are used water elements and lements relad to water, such as: water chanke, wer surfaces, water wals, fountains, continuous weams of $w$ ater, footbridges, floating platforms, watring

Summing up shaping original and of high-quality itban and landsape solutions in cities, where parteservoirs and water een paid on the use of water he identy of a place or the whole city and should help to stop the degradation and unification process of contemporary townscape. Especially the introduction of water elements inspired by history of the development of the area and the local development of the area, both contributes to maintaining the local character of the place and shaping the new identity of the solution. Thanks to the symbiois of various spatial forms, materials used, urban details, water elements, various types of and artificial lighting, new urban landscapes are created.

ENDNOTES

Weichert, Elementy Kompozycii Urbanistycznej, Arkady, Warsawa 1974, s. 99
'lbidem, s. 100 .

Ch. Hölzer, T. Hundt, C. Lüke, O.G. Hamm, Riverscapes. Desig
ning Urban Embankments, Birkhäuser Verlag AG, $2008,1000 \times$
Landscape Architecture, Verlagshaus Braun, 2009, M.S. Braun.
Ch. Hölerer, T. Hundt, C. Lüke, O.G. Hamm, Riverscapes. Designing Urban
Embankments, Birkhäuser Verlag. AG, 2008, 1000 x Landscape ArchitecPublishing AG, 2014, K. Pluta, Przestrze nie publiczne miast europejskich. Projektowanaie urbanistrczzne, Wyd.
poprawione. 2014 . Oficyna Wydawnicza Politechniki Warszawskivi War szawa. K. Pluta, Przestrzenie publiczne miast europejskich...., op. cit.
M.S. Braun, C. Uffelenv, Attas of Word Landscape Architecture, Brau Publishing AG, 2014 K. Pluta, Przestrzenie publiczne miast europejskich..... op. cit.. J. Gehl, L. Gemzee, New city spaces, The Danish Architectural Press, Copenhage
2001, M.S. Braun. C. Uffelenv, Attas of Word Oo. cit. ${ }^{\circ}$ K. Pluta, Przestrzenie publiczne..., op. cit, M.S. Braun, C. Uffelenv, Atlas
of Word..., op.cit., 1000 x Landscape Architecture. Verlagshaus Braun, M.S. Braun, C. Uffelenv, Atlas of Word Landscape Architecture, Brau

Ibidem, s. $182-18$

op. cit s. 117

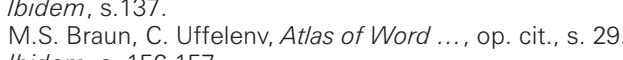

"Ibidem, S. 156-157.
15 K. Pluta. Przestrzenie publiczne miast europeiskich. Projektowanie un

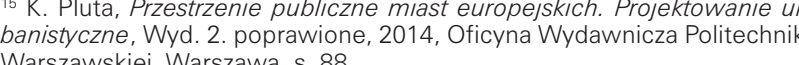

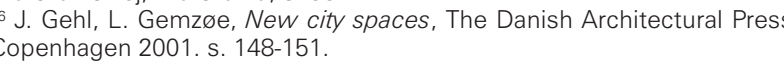

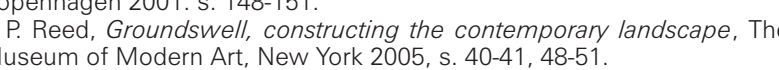
18 M.S. Brauno, C. Uffelenv, Attas ...., op. cit., s.24-25.
.

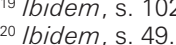

Ibidem, s. 39

ITERATURA

11] Braun M.S., Uffelenv C., Atlas of Word Landscape Architecture, Brau 2) Gehl J., Gemzzee L., New city spaces, The Danish Architectural Press. [3] Hölzer Ch., Hundt T., C. Lüke, O.G. Hamm, Riverscapes. Designing Urban Embankments, Birkhäuser Verlag AG, 2008.
$[4] 1000 \times$ Landscape Architecture. Verlagshaus Braun. 2009.

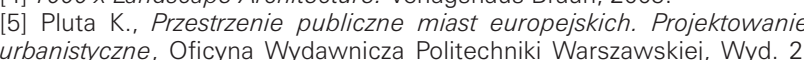
urbanistyczne, Oficyna Wydawnicza Politechniki Warszawskiej, Wyd. 2. poprawione, Groundswell, co cow [7] Wejchert K., Elementy Kompozycii Urbanistycznej, Arkady, Warszaw
C. Uffelenv, Atlas of Word Landscape Architecture, Braun PublisProjektowanie urbanistyczne, Wyd. 2. pooprawione, 2014 Ofickyn K. Pluta, Przestrzenie publiczzne miast europejskich...., op. cit. Braun Publishing AG, 201

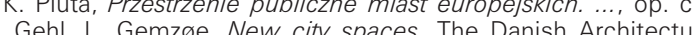
Press, Copenhagen 2001, M.S. Braun, C. Uffelenv, Atas of Whord
. op. cit.
6K. Pluta, Przestrzenie publiczne..., op. cit, M.S. Braun, C. Uffelenv,
A. . Braun, C. Uffelenv, Atlas of Word Landscape Architecture. Ibidem, s. $154-155$
Ibidem, s. $182-183$.

K. Pluta, Przestrzenie publiczne miast europejskich.... op. cit. s. 117.
${ }_{12} /$ bidem, s. 137

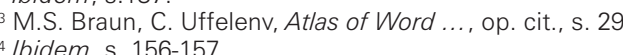

K. Pluta, Przestrzenie publiczne miast europejskich. Projektowa Politechniki Warszawskiej, Warszawa, s. 88 . Danish Architectural
$16 \mathrm{~J}$. Gehl, L. Gemzoe, New city spaces, The Dash Press, Copenhagen 2001. s. 148-151. P. Reed, Groundswell, constructing the contemporary landscape. MS ${ }_{20}^{19} / \mathrm{bidem}$, s. 102.

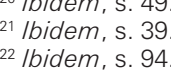

BIBLIOGRAPHY

1] Braun M.S., Uffelenv C., Atlas of Word Landscape Architecture Braun Publishing AG, 2014.

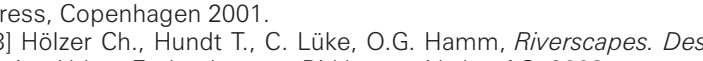
gning Urban Embankments, Birkhäuser Verlag AG, 2008.
[4] 1000 x Landscape Architecture. Verlagshaus Braun. 2009 .

5) Pluta K., Przestrzenie publiczne miast europejskich. Projektowa Wyd. 2. poprawione, 2014, Warszawa.

( [7] Wejchert K. Elementh Art, New York 2005. 